\section{Colostrum as a source of togavirus inhibitors}

Sir,

Human colostrum and milk are rich sources of antimicrobial substances. These afford increased resistance to bacterial and viral infections of the neonatal/infant gastrointestinal and respiratory tracts (Grulee et al., 1935; Goldman and Smith, 1973; Gerrard, 1974) and this must be considered an advantage of breast feeding over the use of substitutes.

My interest in this subject concerns the antiviral behaviour of human colostrum. This stems from the study of nonantibody nonspecific virus inhibitors (NSIs) which occur naturally in serum independent of antigenic stimuli. Colostral NSIs secreted at high level around parturition have been found for representative respiratory viruses, namely influenza, parainfluenza, and adenoviruses (Shortridge, 1970; Shortridge et al., 1974). Detailed study suggested that the influenza virus NSI might be derived from circulating plasma $\alpha_{2}$-macroglobulin. Falkler et al. (1975) in Hawaii recently reported the presence of a lipid-type inhibitor in human colostrum active against dengue virus, an arbovirus.

In continuing studies in Hong Kong, lipoprotein NSIs have been observed in serum (Shortridge and Ho, 1974, 1976) and colostrum for a number of togaviruses including rubella virus and arboviruses such as Aura, Pixuna, Sindbis, Y62-33 (group A); Japanese encephalitis (JE), Ntaya, and Wesselsbron (group B). Colostrum samples from 55 individual Chinese or Caucasian donors ranging from 12 days' preparturition to 3 days' post- were examined and all contained NSI activity for these togaviruses. Strong virus infectivity neutralizing activity was observed using JE virus as a representative virus and there was no evidence that this activity was associated with specific antibody or interferon.

Rubella does not seen to be clinically as important in the Far East as in Western countries (Kono et al., 1969). It is not clear whether the prevalent strains of virus are different or whether there are ethnic differences in susceptibility or response to infection. There is no firm information to hand as to whether the incidence of arbovirus infections such as $\mathrm{JE}$ in the Far East, or rubella in Hong Kong, is less frequent in breast-fed babies. However, as part of a broader study in this field, the serological status of local infants and children for rubella will be evaluated.

A recent report from the World Health Organization has shown very clearly that the rise in infant mortality in rural Chile coincided with a decline in the prevalence of breast feeding (Plank and Milanesi, 1973). While the phylogenetic significance and protective capability of naturally occurring inhibitory substances for arboviruses in particular are unclear, there is continuing evidence of the antiviral behaviour of human colostrum and milk. Such information should not be overlooked in view of the modern trend away from breast feeding in many parts of the world, a trend also evident in Hong Kong.

Some of the colostrum samples used in this study were provided by Dr. R. Wong, Department of Obstetrics and Gynaecology, University of Hong Kong.

K. F. SHORTRIDGE

Department of Microbiology, University of Hong Kong, Pathology Building, Queen Mary Hospital Compound, Hong Kong.

\section{References}

Falkler, W. A., Diwan, A. R., and Halstead, S. B. (1975), A lipid inhibitor of dengue virus in human colostrum and milk; with a note on the absence of anti-dengue secretory antibody. Archives of Virology, 47, 3-10.

Gerrard, J. W. (1974). Breast-feeding: second thoughts. Pediatrics, 54, 757-764.

Goldman, A. S., and Smith, C. W. (1973). Host resistance factors in human milk. Journal of Pediatrics, 82, 10821090.

Grulee, C. G., Sanford, H. N., and Schwartz, H. (1935). Breast and artificially fed infants. Journal of the American Medical Association, 104, 1986-1988.

Kono, R., Hibi, M., Hayakawa, T., and Ishi, K. (1969). Experimental vertical transmission of rubella virus in rabbits. Lancet, 1, 343-347.

Plank, S. J., and Milanesi, M. L. (1973). Infant feeding and infant mortality in rural Chile. Bulletin of the World Health Organization, 48, 203-210.

Shortridge, K. F. (1970). Influenza virus haemagglutination inhibitor in human colostrum: its secretion, possible structure and origin. Clinica Chimica Acta, 29, 233-241.

Shortridge, K. F., and Ho, W. K. K. (1974). Human serum lipoproteins as inhibitors of haemagglutination for selected togaviruses. Journal of General Virology, 23, 113-116.

Shortridge, K. F., and Ho, W. K. K. (1976). Comparison of the activities in inhibition of haemagglutination by different togaviruses for human serum lipoproteins and their constituents. Journal of General Virology, 33, 523-527.

Shortridge, K. F., Ng, M. H., and Wong, R. (1974). Respiratory virus inhibitors in the colostrum of Chinese donors. Journal of Tropical Medicine and Hygiene, 77, 94-102.

\section{Long-term effects of undernutrition in infancy}

Sir,

The recent article (Archives, 1976, 51, 327) by Stoch and Smythe on the ultimate consequences of infantile malnutrition is undoubtedly a valuable one, notwithstanding criticisms which have been levelled at this study previously. I am concerned however that the statistical handling and interpretation of their growth data are not made clear in the published paper. Unfortunately Table I shows what I presume are the mean values for the three variables measured, and there is no indication of the range or distribution of findings among their populations. As a consequence we have the surprising finding that a difference in mean height of $5.6 \mathrm{~cm}$ between index and 
control series among girls is significant at the $P<0.005$ level, whereas a difference of $6.6 \mathrm{~cm}$ between the corresponding groups of boys was not significantly different. The same type of argument can be applied to the weight data, and one is left with the feeling that this might not be a real difference between boys and girls as claimed by the authors in their discussion, but rather simply a consequence of the small sample size making what would otherwise be substantial differences in fact not statistically significant. Alternatively, there may be so much variation between individuals in the index and control groups that this amount of difference is indeed not significant. I think it would strengthen the case being made by the authors with regard to the long-term effects of infantile malnutrition if this additional information could be made available to the reader.

\section{J. A. BIRKBECK Nutrition Department, University of Otago, Box 56, Dunedin, New Zealand.}

Dr. M. B. Stoch and Prof. P. M. Smythe comment:

With apologies, there is an error in our statistics. The group results were computerized but the subgroups were not, which on rechecking by computer showed two errors. The significance of the difference between the index and control girls in regard to height should be $P<0.05$ and not $<0 \cdot 005$. The nonsignificance between index and control boys in regard to height is correct, so the validity of our conclusions is not altered. A similar error was found in the difference between index and control girls in the Bender Visual-Motor Gestalt; the $P$ value for this should also be $<0.05$ and not $<0.005$.

In reply to Prof. Birkbeck's request for information about the range, the figures are given in the Table, together with the figures for weight.

M. B. STOCH and P. M. SMYTHE University of Natal, Faculty of Medicine, Department of Paediatrics and Child Health, P.O. Box 17039, Congella 4013, Durban, South Africa.

\section{Prophylactic isoniazid dosage in newborn infants}

Sir,

Dr. McKenzie and her collaborators (1976) reported in the Archives a case of neonatal pyridoxine-responsive convulsions due to prophylactic anti-TB therapy with isoniazid, in a dose of $13.8 \mathrm{mg} / \mathrm{kg}$ daily. The authors conclude that doses of isoniazid to newborn infants should not be greater than $10 \mathrm{mg} / \mathrm{kg}$ per day. As experience with prophylactic isoniazid administration to newborn infants is limited, I quote here Sifontes (1970), from Puerto Rico, who thinks that a daily dose of 10 $\mathrm{mg} / \mathrm{kg}$ to newborns is not safe, as 'some of these infants become irritable and show signs of central nervous system stimulation which disappear when the dose is lowered'. He suggests a daily dose of $3-5 \mathrm{mg} / \mathrm{kg}$ for the first 2 months of life, which then is increased to $5-10 \mathrm{mg}$ for at least one year.

ALEX. PEONIDES

Children's Asylum Maternity Hospital, Thessaloniki, Greece.

\section{References}

McKenzie, S. A., Macnab, A. J., and Katz, G. (1976). Neonatal pyridoxine responsive convulsions due to isoniazid therapy. Archives of Disease in Childhood, 51, 567-568.

Sifontes, J. E. (1970). Approaches to newborn infants of tuberculous mothers (comment). Year Book of Pediatrics, p. 105. Ed. by S. S. Gellis. Year Book Medical Publishers, Chicago.

Dr. G. Katz comments:

We did not wish to give the impression that $10 \mathrm{mg} / \mathrm{kg}$ per day was the appropriate dose for the neonate, but tried to stress the point that doses in excess of this are dangerous. We are in fact in full agreement with the recommendations of Sifontes.

G. KATZ

Edgware General Hospital, Edgware, Middlesex HA8 OAD.

Table Heights and weights (boys, $n=18 ;$ girls, $n=22)$

\begin{tabular}{|c|c|c|c|c|c|c|}
\hline & \multicolumn{2}{|l|}{ Mean } & \multicolumn{2}{|l|}{$S D$} & \multirow[b]{2}{*}{$t$} & \multirow[b]{2}{*}{$\boldsymbol{P}$} \\
\hline & Index & Control & Index & Control & & \\
\hline \multicolumn{7}{|c|}{ Height $(\mathrm{cm})$} \\
\hline $\begin{array}{l}\text { Boys } \\
\text { Range }\end{array}$ & $\begin{array}{l}157 \cdot 89 \\
148 \cdot 92- \\
174 \cdot 32\end{array}$ & $\begin{array}{l}164 \cdot 54 \\
142 \cdot 24- \\
175 \cdot 89\end{array}$ & $7 \cdot 526$ & $10 \cdot 333$ & $1 \cdot 564$ & NS \\
\hline $\begin{array}{l}\text { Girls } \\
\text { Range }\end{array}$ & $\begin{array}{l}149.20 \\
140.66- \\
160.02\end{array}$ & $\begin{array}{l}154 \cdot 81 \\
146 \cdot 68- \\
166 \cdot 70\end{array}$ & $6 \cdot 132$ & $5 \cdot 596$ & $2 \cdot 238$ & $<0.05$ \\
\hline \multicolumn{7}{|c|}{ Weight $(k g)$} \\
\hline $\begin{array}{l}\text { Boys } \\
\text { Range }\end{array}$ & $\begin{array}{l}44 \cdot 57 \\
35 \cdot 00- \\
55 \cdot 68\end{array}$ & $\begin{array}{l}49 \cdot 42 \\
35 \cdot 00- \\
72 \cdot 73\end{array}$ & $6 \cdot 855$ & $11 \cdot 439$ & $1 \cdot 091$ & NS \\
\hline $\begin{array}{l}\text { Girls } \\
\text { Range }\end{array}$ & $\begin{array}{l}41.63 \\
29.09- \\
56.14\end{array}$ & $\begin{array}{l}47 \cdot 38 \\
39 \cdot 77- \\
55 \cdot 90\end{array}$ & $7 \cdot 975$ & $5 \cdot 022$ & $2 \cdot 021$ & $<0.05$ \\
\hline
\end{tabular}

